\title{
Spawalność stali o podwyższonej wytrzymałości w warunkach podwodnych
}

\author{
Weldability of high strength steels in water environment
}

\section{Streszczenie}

W artykule scharakteryzowano problemy spawalności stali o podwyższonej wytrzymałości w środowisku wodnym. Oceniono eksperymentalnie skłonność do tworzenia pęknięć zimnych stali S355J2G3 i S500M spawanych w warunkach mokrych. Stwierdzono, że badane stale mają dużą skłonnością do pękania. Zaproponowano i sprawdzono doświadczenie przydatność techniki ściegu odpuszczającego jako metody poprawy spawalności stali o podwyższonej wytrzymałości pod wodą w warunkach spawania mokrego.

\section{Wstęp}

Środowisko wodne intensyfikuje oddziaływanie niekorzystnych czynników mających wpływ na skłon-

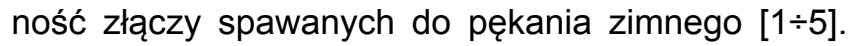
Przeniesienie procesu spawania do środowiska wodnego powoduje przede wszystkim zwiększenie zawartości wodoru dyfundującego w stopiwie oraz szyb-

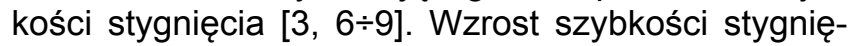
cia przyczynia się do formowania kruchych struktur w strefie wpływu ciepła (SWC) i do wzrostu wartości naprężeń pozostających.

Procesy spawania pod wodą można podzielić na metody suche i mokre. Metody suche polegają na lokalnym odizolowaniu obszaru spawania od otaczającej wody specjalnymi komorami, w których panuje ciśnienie atmosferyczne (spawanie izobaryczne) lub ciśnienie podwyższone wynikające z głębokości spawania (spawanie hiperbaryczne) [6, 10]. Cechą charakterystyczną spawania mokrego jest bezpośredni

Dr inż. Dariusz Fydrych, dr inż. Grzegorz Rogalski, dr hab. inż. Jerzy Łabanowski, prof. PG - Politechnika Gdańska. kontakt nurka-spawacza, elektrody i materiału rodzimego z wodą. Wariantem pośrednim pomiędzy spawaniem mokrym i suchym jest zastosowanie lokalnej komory suchej $[3,9,10]$.

Spośród metod spawania mokrego najczęściej stosowane jest spawanie ręczne elektrodami otulonymi, dlatego większość dostępnych w literaturze wyników badań spawalności stali dotyczy tego procesu. Złącza spawane ze stali konstrukcyjnych wykonywane bezpośrednio w wodzie charakteryzują się wysoką skłonnością do tworzenia pęknięć zimnych. Pęknięcia tworzą się nawet $w$ złączach ze stali o niskim równoważniku węgla $\mathrm{Ce} \leq 0,3 \%$. W obszarze SWC złączy takich stali stwierdzono wzrost twardości do $350 \div 400 \mathrm{HV}$ oraz występowanie licznych mikropęknięć wodorowych

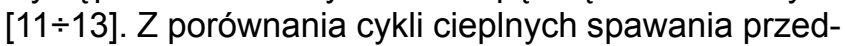
stawionych na rysunku 1 widać, że czasy stygnięcia złączy wykonanych pod wodą są znacznie krótsze niż wykonanych na powietrzu. Zwiększanie ilości wprowadzanego ciepła podczas spawania w pozycji podolnej w mniejszym stopniu powoduje wzrost czasu stygnięcia $t_{8 / 5}$ dla spawania podwodnego, natomiast czasy stygnięcia złączy wykonanych pod wodą w pozycjach pionowych praktycznie nie zależą od ilości wprowadzonego ciepła, co można tłumaczyć powstawaniem silniejszych prądów konwekcyjnych (rys. 2) [6]. 


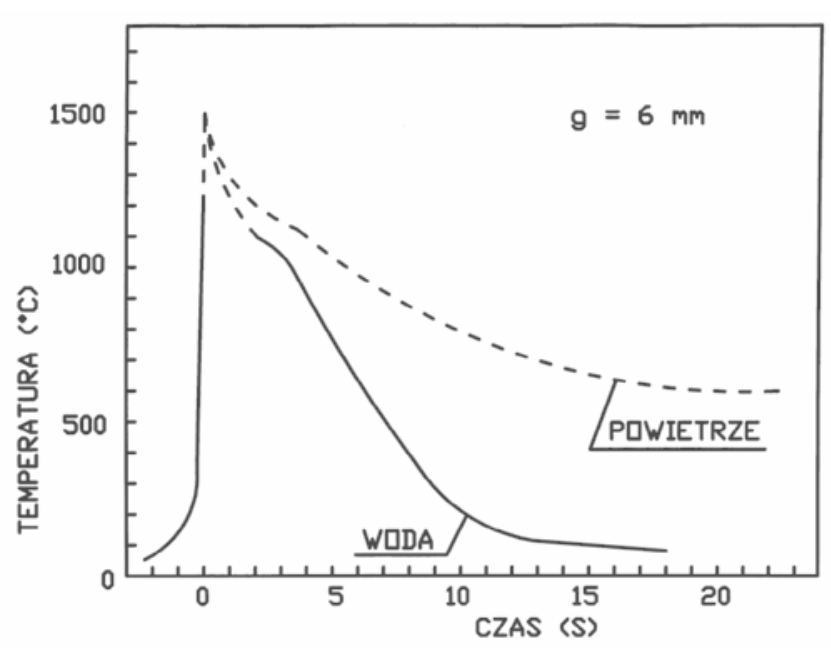

Rys. 1. Porównanie cykli cieplnych spawania w środowisku powietrznym i wodnym, spawanie MMA, złącze doczołowe blach o grubości $6 \mathrm{~mm}[14]$

Fig. 1. Comparison of welding thermal cycles in air and water environment, MMA, BW, plate thickness $6 \mathrm{~mm}$ [14]

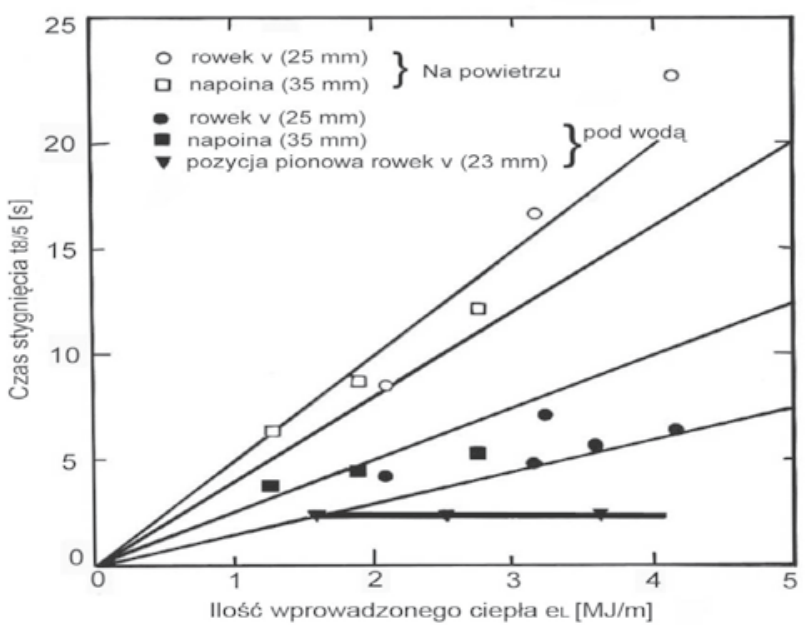

Rys. 2. Zależność czasu stygnięcia złącza od ilości wprowadzonego ciepła [6]: ○ - spawanie na powietrzu, $\bullet$ - spawanie pod wodą - - napawanie a powietrzu, $\cdot$ - napawanie pod wodą, $\bullet$ - spawanie pod wodą w pozycji pionowej

Fig. 2. Effect of heat input on cooling time [6]: ○ - welding in air, • welding under water, 口 - overlaying in air, $\cdot-$ overlaying under water, - - welding under water in vertical position

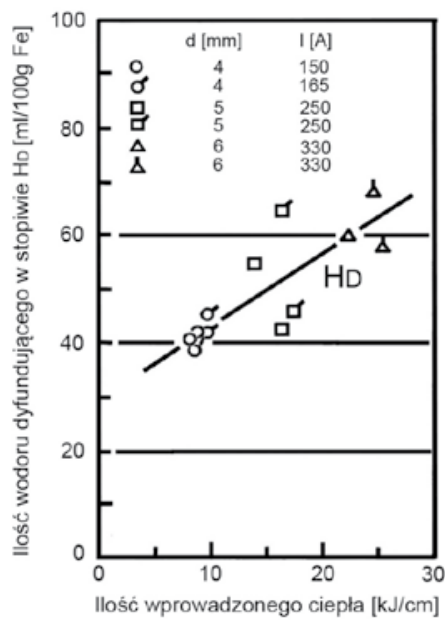

Rys. 3. Wpływ ilości wprowadzonego ciepła przy spawaniu mokrym MMA na zawartość wodoru dyfundującego w stopiwie [16]

Fig. 3. Effect of heat input of MMA wet welding on diffusible hydrogen content in deposited metal [16]
Spawanie elektrodami otulonymi w warunkach mokrych generuje ilości wodoru dyfundującego w stopiwie rzędu kilkudziesięciu ml/100 g Fe w zależności od rodzaju otuliny i warunków spawania [12, 15]. Badania wykonane przy użyciu najczęściej stosowanych w takich warunkach elektrod o otulinie rutylowej wykazały, że zawartość wodoru w stopiwie nie zależy od stopnia zawilgocenia otuliny i zastosowanej warstwy ochronnej, natomiast decydującym czynnikiem jest ilość wprowadzonego ciepła (rys. 3) [15, 16].

Na rysunku 4 pokazano wyniki uzyskane z prób Tekken wykonanych pod wodą, które posłużyły do opracowania równania pozwalającego na wyznaczenie minimalnej ilości wprowadzonego ciepła zabezpieczającego przed formowaniem pęknięć zimnych [6].

Równanie to ma następującą postać:

$$
q=200 \times(P-T / 600)-67
$$

gdzie: $\mathrm{P}=\mathrm{Ce}+\mathrm{HD} / 60+\mathrm{R} / 200$ 000, q - ilość wprowadzonego ciepła $\mathrm{kJ} / \mathrm{cm}$; Ce - równoważnik węgla wg MIS\%; HD - zawartość wodoru dyfundującego w stopiwie, ml/100g Fe; R - intensywność utwierdzenia, MPa; $\mathrm{T}$ - temperatura podgrzewania wstępnego, ${ }^{\circ} \mathrm{C}$.

Badania przeprowadzone na próbkach Implant wykonane w podobnych warunkach jak próby Tekken wykazały, że naprężenia krytyczne są wyższe od granicy plastyczności badanej stali [17]. Świadczy to o odporności stali na pękanie i nie jest zgodne z wynikami badań [6].

Duża liczba czynników zmiennych podczas spawania podwodnego uniemożliwia precyzyjne określenie bezpiecznych warunków spawania - takich, które zabezpieczą wykonywane złącza przed powstawaniem pęknięć. Jednak na podstawie wielu badań określono orientacyjne kryteria bezpiecznego spawania mokrego stali niestopowych [18]:

- równoważnik węgla dla materiału rodzimego $\mathrm{Ce}<0,30 \%$,

- ilość wprowadzonego ciepła wyższa od 1,5 kJ/mm.

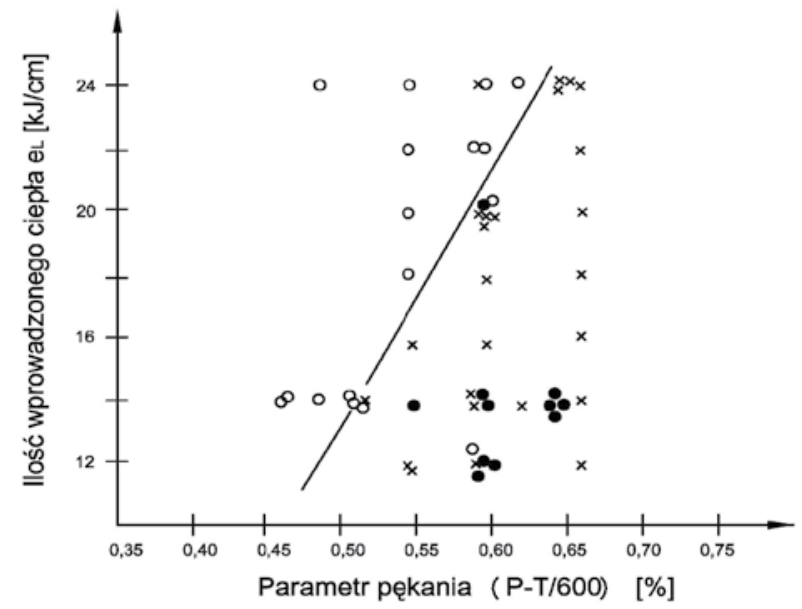

Rys. 4. Wyniki prób Tekken dla spawania mokrego MMA pod wodą [6]: o - brak pęknięć, $\times$ - pęknięcia wewnętrzne, $\bullet-$ pęknięcia wewnętrzne i zewnętrzne

Fig. 4. Results of Tekken tests, underwater wet MMA welding [6]: $\circ-$ no cracks, $x$ - internal cracks, $\bullet-$ internal and external cracks 
W przypadku zastosowania elektrod austenitycznych wartość równoważnika węgla spawanej stali może być wyższa - nawet do $0,4 \%$. Wtedy należy jednak liczyć się z możliwością wystąpienia pęknięć gorących w spoinie [6, 20]. Zmniejszenie skłonności do tworzenia pęknięć zimnych stali dzięki spawaniu mokrym można także osiągnąć przez zastosowaniu elektrod niskostopowych zawierających nikiel. Za optymalną zawartość niklu w spoiwie przyjmuje się $2 \%$ [19].

Inną metodą ograniczenia skłonności do powstawania pęknięć zimnych jest zastosowanie techniki ściegu odpuszczającego (Temper Bead Welding -TBW) [21, 22]. W technologii TBW uzyskuje się redukcję naprężeń pozostających po spawaniu oraz zmniejszenie twardości SWC. Technologia ta stosowana jest dla złączy elementów o dużej grubości, tam gdzie nie można wykonać obróbki cieplnej po spawaniu. Polega ona na nakładaniu kolejnych ściegów na spoinę, co powoduje lokalną obróbkę cieplną w obszarze wcześniej nałożonej warstwy spawanej. W SWC tej warstwy mogą zachodzić przemiany strukturalne w zakresie temperatur wyższych od temperatury $A_{c 1}$. Przepisy ASME wymagają nakładania sześciu warstw, przy czym dla pierwszych trzech warstw często stosuje się rosnące ilości wprowadzonego ciepła [21]. W przypadku wykorzystania techniki TBW do zapobiegania formowania się pęknięć zimnych istotne jest określenie czasu pomiędzy położeniem ściegu odpuszczanego i odpuszczającego. W zależności od typu zastosowanej elektrody czas do tworzenia się pęknięć przy spawaniu mokrym może wynosić od 3 minut do 2 godzin. Kolejnymi ważnymi z punktu widzenia skuteczności procesu parametrami są: ilość wprowadzanej energii cieplnej w każdym ściegu oraz odległość między osiami ściegów (podziałka) [21].

\section{Badania własne}

Celem badań było określenie skłonności do tworzenia pęknięć zimnych złączy ze stali o podwyższonej wytrzymałości wykonanych metodą mokrą elektrodami otulonymi. Badania prowadzono wg następującego planu:

- przygotowanie stanowisk do spawania w środowisku powietrznym i pod wodą,

- przygotowanie próby technologicznej Tekken,

- wykonanie złączy próbnych,

- badania penetracyjne,

- badania metalograficzne makro- i mikroskopowe,

- pomiary twardości metodą Vickersa.

Dodatkowo, w celu oceny przydatności stosowania techniki ściegu odpuszczającego do poprawy spawalności stali w środowisku wodnym, wykonano napoiny próbne i poddano je badaniom metalograficznym makroskopowym i pomiarom twardości.

Do badań użyto blach o grubości $15 \mathrm{~mm}$ ze stali S355J2G3 oraz S500M. Skład chemiczny stali oraz ich właściwości mechaniczne podano w tablicach I i ll.

Spoiny próbne wykonano elektrodami OMNIA (E 42 ORC 11) firmy Lincoln Electric o średnicy $4 \mathrm{~mm}$. Są to elektrody rutylowe ogólnego przeznaczenia do spawania we wszystkich pozycjach o składzie chemicznym: C - 0,07\%, Mn - 0,5\%, Si - 0,5\% i właściwościach mechanicznych stopiwa: $R_{e}-\min .420 \mathrm{MPa}$, $R_{m}-500 \div 640 \mathrm{MPa}, A_{5}-\min 20 \%$ [23].

Wykonano złącza próbne Tekken ze stali S500M pod wodą $w$ środowisku powietrznym oraz złącza ze stali S355J2G3 pod wodą przy różnej ilości wprowadzanego ciepła spawania. Złącza próbne wykonano zgodnie $z$ wytycznymi normy [24]

Tablica I. Skład chemiczny badanych stali S355J2G3 i S500M

Table I. Chemical composition of investigated S355J2G3 and S500M steels

\begin{tabular}{|c|c|c|c|c|c|c|c|c|c|c|}
\hline Stal & \multicolumn{10}{|c|}{ Zawartość składników, \% wag. } \\
\hline \multirow{2}{*}{ S355J2G3 } & C & Si & $\mathrm{Mn}$ & $P$ & $\mathrm{~S}$ & $\mathrm{Cr}$ & $\mathrm{Ni}$ & $\mathrm{Cu}$ & $\mathrm{Al}$ & $\mathrm{Ce}$ \\
\hline & 0,17 & 0,35 & 1,44 & 0,014 & 0,014 & 0,04 & 0,077 & 0,30 & 0,02 & 0,44 \\
\hline \multirow{2}{*}{ S500M } & C & $\mathrm{Si}$ & $\mathrm{Mn}$ & $\mathrm{P}$ & $\mathrm{S}$ & $\mathrm{Nb}$ & $\mathrm{V}$ & $\mathrm{Ti}$ & $\mathrm{Al}$ & $\mathrm{Ce}$ \\
\hline & 0,067 & 0,018 & 1,380 & 0,009 & 0,002 & 0,056 & 0,054 & 0,001 & 0,039 & 0,30 \\
\hline
\end{tabular}

Tablica II. Właściwości mechaniczne blach grubości $15 \mathrm{~mm}$ ze stali S355J2G3 i S500M

Table II. Mechanical properties of S355J2G3 and S500M steels, plate thickness $15 \mathrm{~mm}$

\begin{tabular}{|c|c|c|c|}
\hline \multirow{2}{*}{ Stal } & \multicolumn{3}{|c|}{ Właściwości mechaniczne } \\
\cline { 2 - 4 } & $\mathrm{R}_{\mathrm{e}}, \mathrm{MPa}$ & $\mathrm{R}_{\mathrm{m}}, \mathrm{MPa}$ & $\mathrm{A}_{5}, \%$ \\
\hline S355J2G3 & 464 & 577 & 22,1 \\
\hline S500M & 525 & 619 & 20,5 \\
\hline
\end{tabular}

Tablica III. Warunki wykonania próbek Tekken

Table III. Conditions of Tekken tests

\begin{tabular}{|c|c|c|c|c|c|c|}
\hline \multirow{2}{*}{ Nr próbki } & \multirow{2}{*}{ Stal } & \multirow{2}{*}{ Środowisko } & \multicolumn{2}{|c|}{ Parametry spawania } & \multirow{2}{*}{$\begin{array}{c}\text { Czas spawania t } \\
\text { s }\end{array}$} & \multirow{2}{*}{$\begin{array}{l}\text { Ilość wprowadzonego ciepła q } \\
\text { kJ/mm }\end{array}$} \\
\hline & & & $\mathrm{U}, \mathrm{V}$ & $\mathrm{I}, \mathrm{A}$ & & \\
\hline W1 & S500M & woda & 30,0 & 228 & 16,4 & 1,40 \\
\hline W2 & S500M & woda & 34,3 & 232 & 18,5 & 1,85 \\
\hline W3 & S500M & woda & 32,5 & 244 & 16,9 & 1,68 \\
\hline P6 & S500M & powietrze & 22,0 & 168 & 30,0 & 1,39 \\
\hline P12 & S500M & powietrze & 24,3 & 160 & 31,0 & 1,51 \\
\hline $1 \mathrm{~A}$ & S355J2G3 & woda & 30,8 & 228 & 33,0 & 2,90 \\
\hline $2 \mathrm{~A}$ & S355J2G3 & woda & 29,2 & 232 & 29,0 & 2,44 \\
\hline
\end{tabular}


na stanowisku do spawania pod wodą na małej głębokości [3]. Warunki wykonania prób Tekken dla wybranych złączy zestawiono w tablicy III.

\section{Badania penetracyjne}

Badania penetracyjne złączy próbnych wykonano po upływie 72 godzin od zakończenia spawania $[25,26]$. Stwierdzono występowanie pęknięć w spoinach we wszystkich próbkach wykonanych w środowisku wodnym, przy czym pęknięcia w złączach ze stali S355J2G3 przebiegały w pobliżu linii wtopienia, natomiast w próbkach ze stali S500M w osi spoiny. $\mathrm{Na}$ próbkach Tekken spawanych w powietrzu pęknięć nie wykryto.

\section{Badania metalograficzne makroskopowe}

Badania metalograficzne makroskopowe przeprowadzono zgodnie z wytycznymi normy [27]. Przykładowe fotografie przekrojów przedstawiono na rysunkach $5 \div 7$. W próbkach wykonanych pod wodą stwierdzono występowanie rozległych pęknięć oraz niekiedy ograniczonej liczby pęcherzy gazowych. Próbki Tekken ze stali S500M wykonane w powietrzu charakteryzowały się znacznie mniejszą skłonnością do pękania, jednak na jednej z nich też stwierdzono pęknięcia. Otrzymane wyniki prób Tekken zestawiono w tablicy IV.

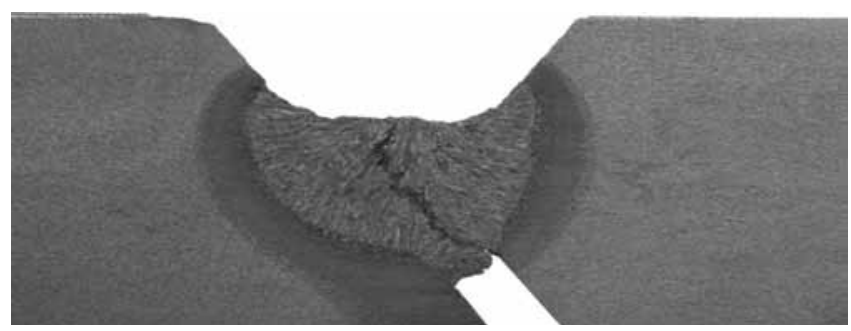

Rys. 5. Przekrój złącza próbnego W1 (S500M) z pęknięciem w spoinie zainicjowanym w grani. Traw. nital

Fig. 5. Cross section of test joint with crack initiated in weld root. Etch: nital

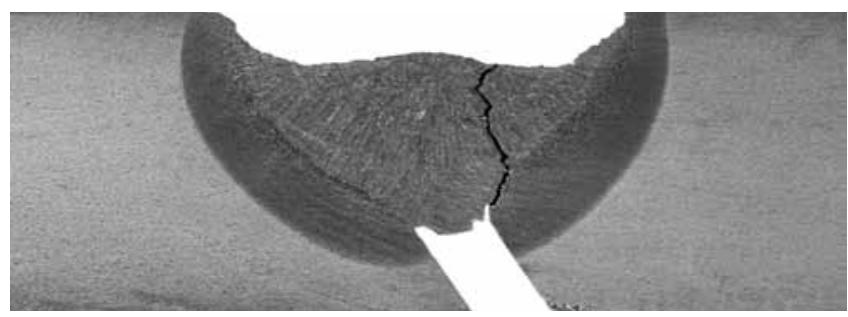

Rys. 6. Przekrój złącza próbnego 1A (S355J2G3) z pęknięciem w spoinie zainicjowanym w linii wtopienia. Traw. nital

Fig. 6. Cross section of test joint with crack initiated in fusion line. Etch: nital

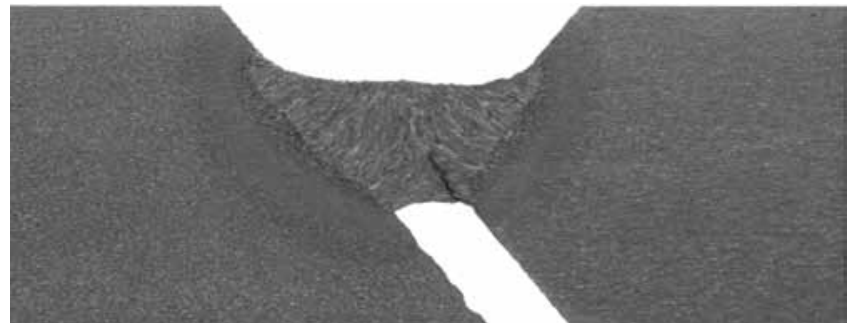

Rys. 7. Przekrój złącza próbnego P12 (S500M) z pęknięciem w spoinie zainicjowanym w grani. Traw. nital

Fig. 7. Cross section of test joint with crack initiated in weld root. Etch: nital

Tablica IV. Zestawienie wyników prób Tekken Table IV. Results of Tekken tests

\begin{tabular}{|c|c|c|c|c|c|c|}
\hline \multirow{2}{*}{ Nr próbki } & \multirow{2}{*}{ Środowisko } & \multirow{2}{*}{ Badania penetracyjne } & \multirow{2}{*}{$\begin{array}{c}\text { Badania metalograficz- } \\
\text { ne makroskopowe }\end{array}$} & \multirow{2}{*}{$\begin{array}{c}\text { Badania twardości } \\
\text { HV, } 10 \text { max }\end{array}$} & \multicolumn{2}{|c|}{ Procentowy udział pęknięć } \\
\hline & & & & & $\mathrm{C}_{\mathrm{f}} \%$ & $\mathrm{C}_{\mathrm{s}}, \%$ \\
\hline W1.1 & \multirow{2}{*}{ woda } & pęknięcie & pęknięcie & 258 & \multirow{2}{*}{40} & 61 \\
\hline W1.2 & & pęknięcie & pęknięcie & 294 & & 79,3 \\
\hline W2.1 & \multirow{2}{*}{ woda } & pęknięcie & pęknięcie & 283 & \multirow{2}{*}{27,5} & 44,4 \\
\hline W2.2 & & pęknięcie & pęknięcie & 287 & & 81,4 \\
\hline W3.1 & \multirow{2}{*}{ woda } & pęknięcie & pęknięcie & 262 & \multirow{2}{*}{43,8} & 73,3 \\
\hline W3.2 & & pęknięcie & pęknięcie & 298 & & 62,5 \\
\hline P6.1 & \multirow{2}{*}{ powietrze } & brak pęknięcia & brak pęknięcia & 248 & \multirow{2}{*}{0} & 0 \\
\hline P6.2 & & brak pęknięcia & brak pęknięcia & 242 & & 0 \\
\hline P12.1 & powietrze & pęknięcie & pęknięcie & 251 & \multirow{2}{*}{18,5} & 30 \\
\hline P12.2 & powietrze & pęknięcie & pęknięcie & 240 & & 27 \\
\hline $1 \mathrm{~A} .1$ & woda & pęknięcie & pęknięcie & 417 & \multirow{2}{*}{100} & 83 \\
\hline $1 \mathrm{~A} .2$ & woda & pęknięcie & pęknięcie & 413 & & 100 \\
\hline $2 \mathrm{~A} .1$ & woda & pęknięcie & pęknięcie & 430 & \multirow{2}{*}{100} & 78 \\
\hline $2 A .2$ & woda & pęknięcie & pęknięcie & 421 & & 90 \\
\hline
\end{tabular}




\section{Badania metalograficzne mikroskopowe}

Na rysunku 8 przedstawiono typowe struktury materiału rodzimego, spoiny i SWC przy linii wtopienia dla badanych złączy wykonanych pod wodą. Struktura stali S500M składa się z ziaren ferrytu o bardzo zróżnicowanej wielkości ze śladową zawartością perlitu, podczas gdy stal S355J2G3 wykazuje strukturę ferrytyczno-perlityczną z wyraźną pasmowością. Struktura spoin obu stali jest podobna i składa się $z$ ferrytu w układzie kolumnowym z zarysem struktury Widmannstättena. W SWC stali S500M widać struktury quasiiperlitu $\mathrm{z}$ iglastymi pasmami ferrytu sięgającymi w głąb ziaren, natomiast w SWC stali S355J2G3 widoczne są iglaste struktury hartowania.

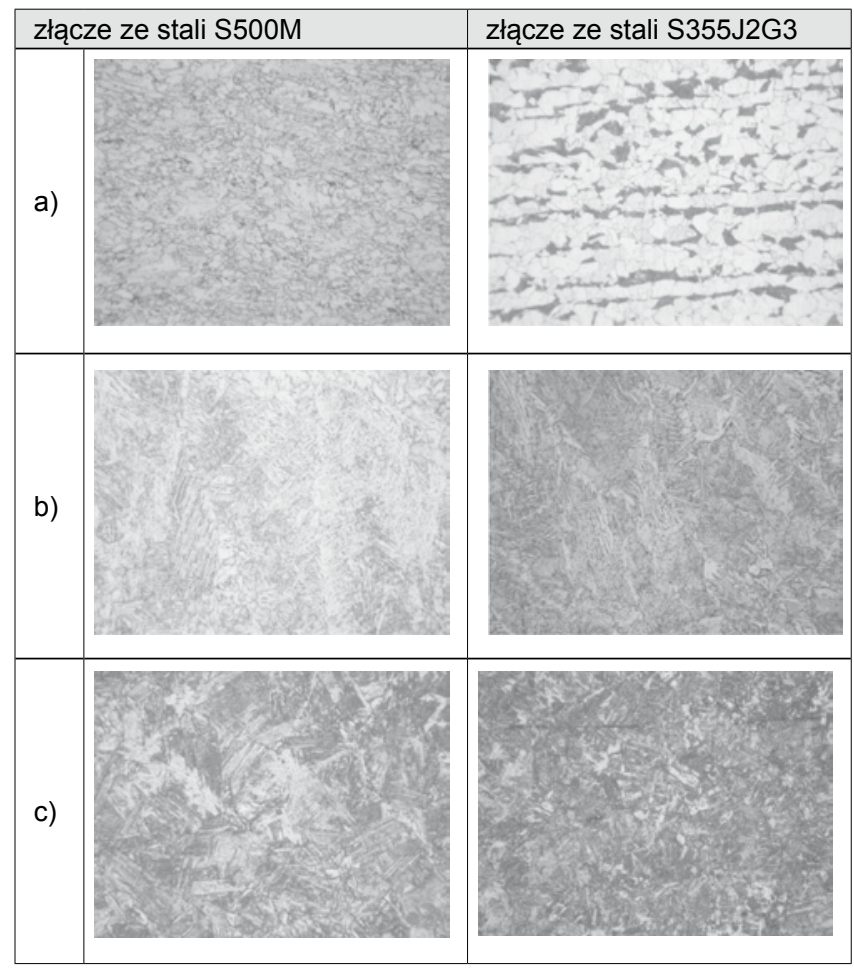

Rys. 8. Mikrostruktura złączy ze stali S500M i S355J2G3 spawanych pod wodą: a) materiał rodzimy, b) spoina, c) SWC - obszar przegrzania, pow. $200 x$

Fig. 8. Microstructure of S500M and S355J2G3 steels joints; a) base material, b) weld, c) overheated zone in HAZ. Magn. 200x

\section{Badanie twardości złączy}

Pomiary twardości przeprowadzono zgodnie z normą [28] przy obciążeniu 98 N (HV10). Przykładowe wyniki pokazano na rysunkach $9 \div 11$. W złączach ze stali S500M wykonanych zarówno na powietrzu, jak i pod woda, twardość spoiny i materiału rodzimego była zbliżona i wynosiła ok. 200 HV10. W SWC obserwowano niewielkie zwiększenie twardości do 240 HV10 przy spawaniu w powietrzu, natomiast przeniesienie spawania do środowiska wodnego spowodowało dalszy wzrost twardości maksymalnej SWC średnio o 40 HV10 (do ok. 280 HV10).

Twardości maksymalne w SWC złączy ze stali S355J2G3 były już znacząco wyższe. Większa zawartość węgla $w$ stali spowodowała podhartowanie w SWC i wzrost twardości do ponad 400 HV10.

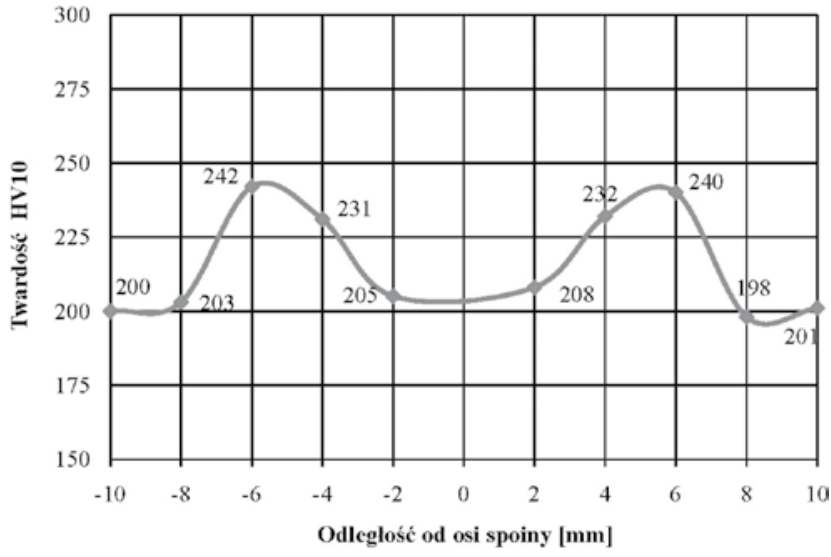

Rys. 9. Rozkład twardości złącza próbnego P6, stal S500M spawana na powietrzu HV max $=242$

Fig. 9. Hardness distribution across P6 joint, steel S500M welded in the air, HV $\max =242$

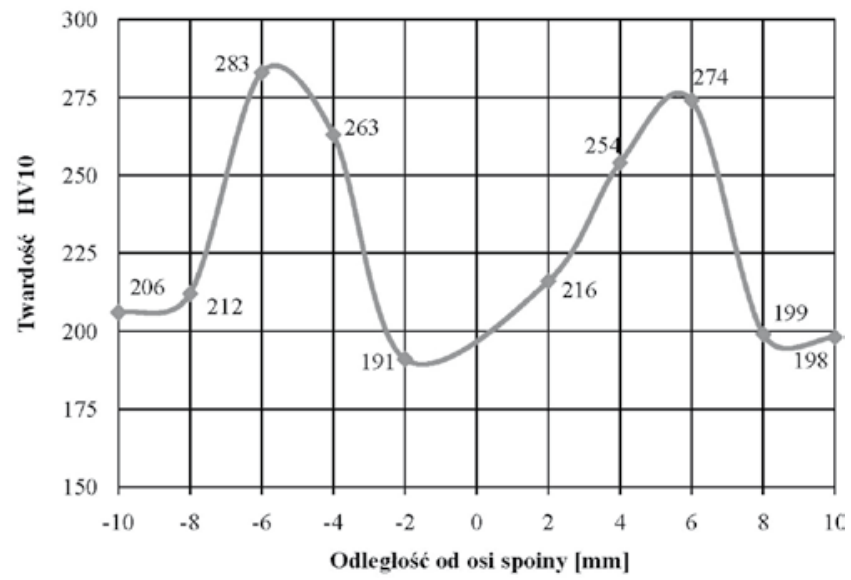

Rys. 10. Rozkład twardości złącza próbnego W2, stal S500M spawana pod wodą, HV max $=283$

Fig. 10. Hardness distribution across W2 joint, steel S500M welded under water, HV $\max =283$

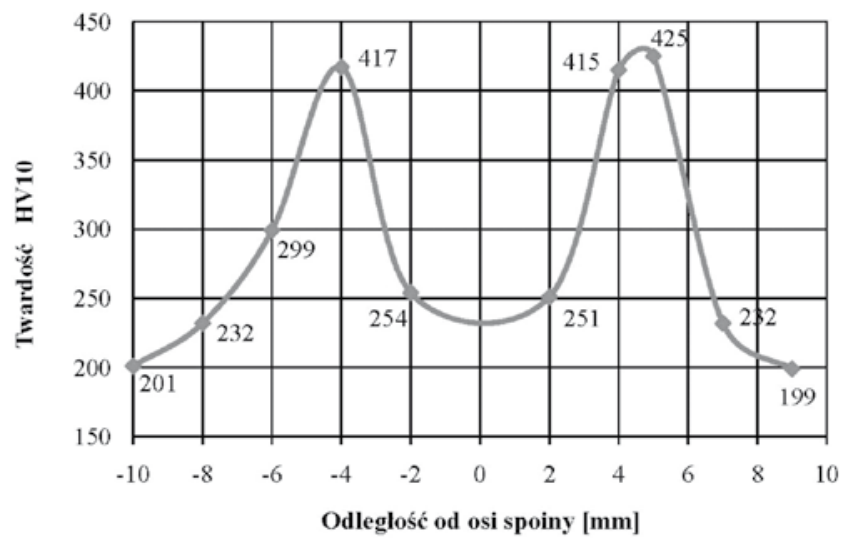

Rys. 11. Rozkład twardości złącza próbnego 1A, stal S355J2G3 spawana pod wodą, HV max $=425$

Fig. 11. Hardness distribution across $1 \mathrm{~A}$ joint, steel S355J2G3 welded under water, HV $\max =425$ 


\section{Zastosowanie techniki ściegu odpuszczającego}

Wstępną ocenę przydatności zastosowania techniki ściegu odpuszczającego do poprawy spawalności w środowisku wodnym przeprowadzono na płytach ze stali S355J2G3. Na płycie próbnej o wymiarach $12 \times 100 \times 200 \mathrm{~mm}$ wykonano napoiny elektrodami Omnia w odstępie $10 \mathrm{~min}$. i z podziałką 40\%. Przekroje napoin poddano badaniom metalograficznym makroskopowym oraz pomiarom twardości. Parametry napawania zestawiono w tablicy V. Zgład makroskopowy z zaznaczeniem kolejności wykonania napoin pokazano na rysunku 12.

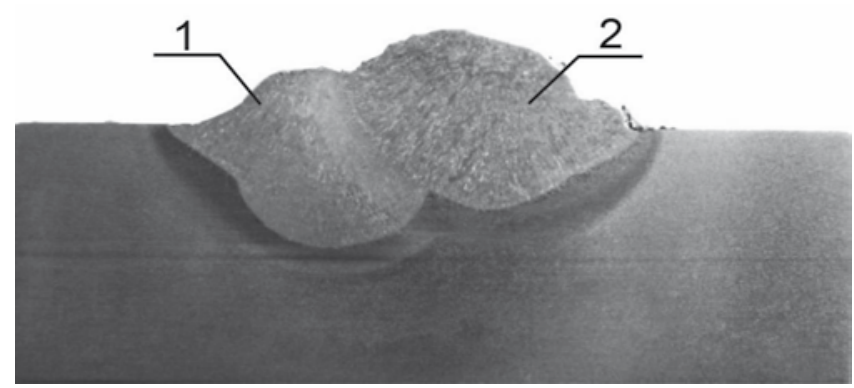

Rys. 12. Przekrój napoin próbnych, stal S355J2G3, podziałka $40 \%$ Fig. 12. Cross section of test weld beads, steel S355J2G3, pitch $40 \%$

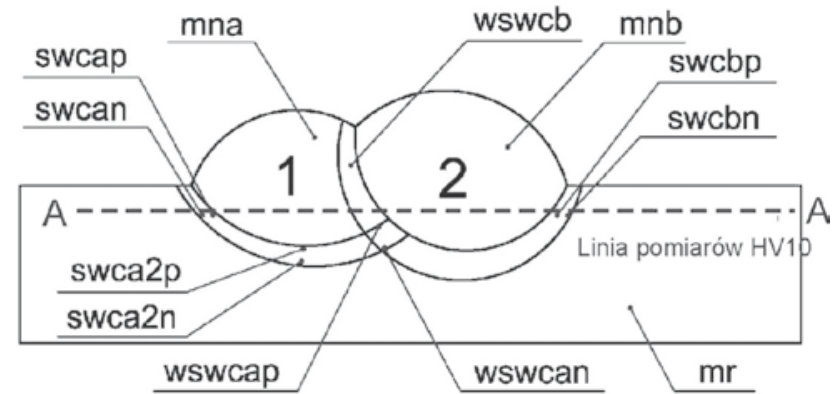

Rys. 13. Lokalizacja i oznaczenia badanych stref płyt próbnych: mr - materiał rodzimy, mna - napoina pierwsza, mnb - napoina druga, swca - SWC napoiny pierwszej, swcb - SWC napoiny drugiej, wswca - strefa zachodzących na siebie swca i swcb, wswcb - strefa swcb zachodząca w strefę mna, $n$ - strefa normalizacji, $p$ - strefa przegrzania

Fig. 13. Location and designation of investigated zones at test plate: $\mathrm{mr}$ - base material, mna - first padding weld, mnb - second padding weld, swca - HAZ of first padding weld, swcb - HAZ of second padding weld, swca and sweb overlop area, wswcb - sweb overlap in $\mathrm{mna}, \mathrm{n}$ - standarization area, $\mathrm{p}$ - overheat area

Tablica V. Parametry napawania stali S355J2G3 Table V. Welding parameters of S355J2G3 steel

\begin{tabular}{|c|c|c|c|c|}
\hline$\frac{\mathbb{0}}{\overline{\frac{C}{O}}}$ & $\begin{array}{c}\text { Natężenie } \\
\text { prądu } \\
\text { spawania } \\
\text { I, A }\end{array}$ & $\begin{array}{c}\text { Napięcie } \\
\text { łuku U, V }\end{array}$ & $\begin{array}{c}\text { Prędkość } \\
\text { spawania } \\
\mathrm{v}, \mathrm{mm} / \mathrm{min}\end{array}$ & $\begin{array}{c}\text { Ilość } \\
\text { wprowadzonego } \\
\text { ciepła, } \mathrm{kJ} / \mathrm{mm}\end{array}$ \\
\hline 1 & 206 & 34,5 & 255 & 1,67 \\
\hline 2 & 226 & 41,0 & 213 & 2,60 \\
\hline
\end{tabular}

Na rysunku 13 wskazano lokalizacje i oznaczenia obszarów, w których zostały wykonane pomiary twardości, natomiast $w$ tablicy VI i na rysunku 14 zamieszczono wyniki pomiarów twardości w odległości $2 \mathrm{~mm}$ od powierzchni próbki.

Przedstawione wyniki pomiarów twardości dla napoin pozwalają stwierdzić, że technika ściegu odpuszczającego przy spawaniu podwodnym umożliwia obniżenie twardości maksymalnej w SWC do poziomu bezpiecznego ze względu na możliwość formowania się pęknięć zimnych. Na rysunku 14 można zauważyć dwa charakterystyczne punkty wzrostu twardości (swcap i swcbp). Występują one przy linii wtopienia i jednocześnie bardzo blisko krawędzi napawanych elementów. W miejscu tym następuje intensywne odprowadzanie ciepła m.in. na drodze wrzenia pęcherzykowego, co prowadzi do formowania się struktur o wysokiej twardości. Przy wykonywaniu złączy wielościegowych takie zjawisko może zostać zminimalizowane poprzez ponowne dostarczanie ciepła podczas wykonywania kolejnych ściegów odpuszczających - w rozpatrywanym przypadku w czasie wykonywanym ostatniego ściegu pomiędzy dwoma napoinami.

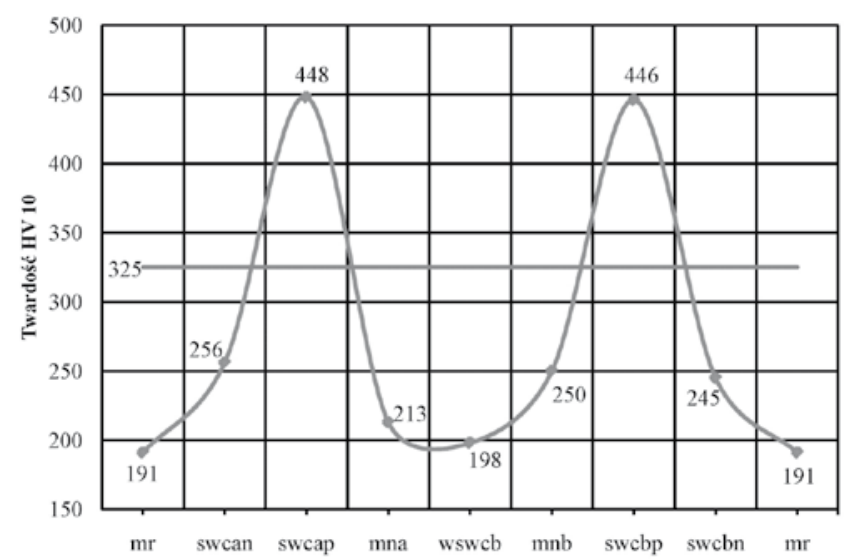

Rys. 14. Rozkład twardości wzdłuż linii A-A (rys. 13) na płycie próbnej ze stali S355J2G3. Poziomą linią zaznaczono HVmax strefy odpuszczonej w SWC pierwszej napoiny (swca2p)

Fig. 14. Hardness pattern in line A-A (fig. 13) at test plate S355J2G3 steel. HV max of tempered zone of first weld bead HAZ was marked by horizontal line

Tablica VI. Wyniki badań twardości płyt próbnych ze stali S355J2G3 Table VI. Results of hardness tests

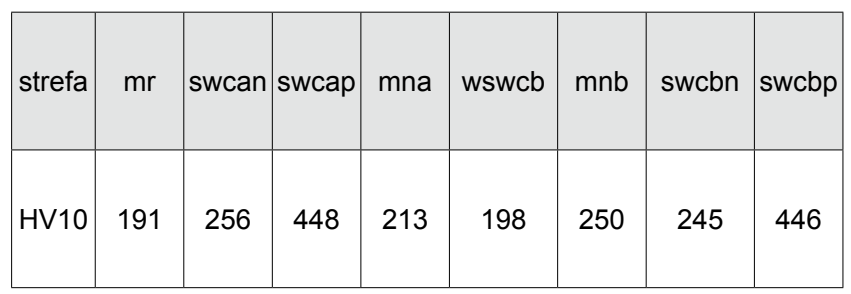

\begin{tabular}{|c|c|c|c|c|c|}
\hline strefa & $\mathrm{mr}$ & swca2n & swca2p & wswcan & wswcap \\
\hline HV10 & 191 & 251 & 325 & 223 & 260 \\
\hline
\end{tabular}




\section{Podsumowanie}

We wszystkich złączach próbnych wykonanych pod wodą stwierdzono występowanie pęknięć w spoinach. Jest to zjawisko zgodne $\mathrm{z}$ informacjami zawartymi w literaturze dotyczącej spawalności badanych stali $[2,4,5]$. Próbki wykonane w powietrzu charakteryzowały się znacznie mniejszą skłonnością do pękania. Obecność pęknięć w złączach wykonanych w środowisku powietrznym spowodowana jest zastosowaniem elektrod rutylowych. Zastosowanie tego rodzaju elektrod uwarunkowane było odniesieniem badań do warunków rzeczywistych spawania pod wodą metodą 111 (najczęściej stosowane są elektrody o otulinie rutylowej) oraz zbieżnością z wymaganiami normy PN-EN ISO 15618-1 dotyczącej certyfikowania nurków spawaczy przy spawaniu mokrym [29]. W normie tej jedną z zalecanych elektrod do spawania jest elektroda o otulinie rutylowej. Spawanie elektrodami rutylowymi, zarówno w środowisku powietrznym, jak i podwodnym, jest procesem wysokowodorowym. Na podstawie wcześniejszych doświadczeń zawartość wodoru dyfundującego $w$ stopiwie $w$ środowisku powietrznym można ocenić na ok. $35 \mathrm{ml} / 100 \mathrm{~g} \mathrm{Fe}$, natomiast w przypadku spawania pod wodą na $50 \mathrm{ml} / 100 \mathrm{~g} \mathrm{Fe}[15,30]$.

W warunkach spawania mokrego stali S500M nastąpił wzrost twardości maksymalnej SWC z 240 $\div 250$ HV10, charakterystycznej dla spawania w środowisku powietrznym, do $260 \div 300$ HV10. Twardości maksymalne w SWC stali S500M są niższe od wartości 350 HV 10, uznawanej za krytyczną z punktu widzenia odporności na pękanie zimne. Natomiast złącza próbne ze stali S355J2G3 charakteryzowały się znacznie wyższą twardością maksymalną SWC - o wartościach powyżej 400 HV10. Wynika to z warunków spawania (m.in. zwiększone prędkości stygnięcia, a tym samym skrócone czasy stygnięcia $t_{815}$ ), które przy równoważniku węgla $\mathrm{Ce}=0,44 \%$ dla stali S355J2G3 doprowadziły do formowania się struktur hartowniczych. Charakterystyczne dla próbek Tekken, dla stali S355J2G3 jest inicjowanie pęknięć z linii wtopienia, co potwierdza obecność kruchych struktur w tym obszarze (rys. 7). Rozkład twardości na przekroju złączy Tekken dla stali S500M spełnia kryteria przy zatwierdzaniu technologii spawania dla spawania na powietrzu. Ograniczenie twardości maksymalnej SWC poniżej 350 HV10 jest efektem niskiej zawartości węgla w stali oraz równoważnika węgla $\mathrm{Ce}=0,30 \%$. Przedstawione wyniki wskazują na przydatność niskowęglowych stali wysokowytrzymałych po walcowaniu cieplno-mechanicznym na konstrukcje hydrotechniczne wymagające spawania podwodnego.

Zastosowanie techniki ściegu odpuszczającego dla stali S355J2G3 umożliwiło uzyskanie zadowalającej twardości w newralgicznych obszarach napoin (tabl. V). Technika ta jest niezwykle przydatna przy spawaniu elementów ze stali wymagającej np. obróbki cieplnej po spawaniu. W warunkach spawania mokrego, czy suchego hiperbarycznego, taki zabieg byłby bardzo kosztowny, a w większości przypadków niemożliwy do zrealizowania. Tego rodzaju technika pozwala na uzyskanie złączy spawanych spełniających kryteria norm przedmiotowych czy towarzystw klasyfikacyjnych przy zastosowaniu dość prostych zabiegów technologicznych. Może znaleźć to zastosowane np. do naprawach rurociągów podmorskich. Należy zaznaczyć, że jakość ściegów odpuszczających zależy od wielu czynników, m.in. od pozycji spawania, natężenia prądu spawania, prędkości przejścia, długości łuku, kąta ustawienia palnika czy ilości wprowadzonego ciepła. Kolejne badania powinny uwzględniać te zmienne, co pozwoli na określenie optymalnych warunków zastosowania techniki ściegu odpuszczającego przy spawaniu pod wodą.

\section{Wnioski}

Złącza stali S355J2G3 i S500M wykonane pod wodą $w$ warunkach utwierdzenia wykazały wysoką skłonność do tworzenia pęknięć zimnych w spoinie.

We wszystkich złączach próbnych Tekken ze stali S500M, wykonanych metodą mokrą stwierdzono występowanie pęknięć zimnych, natomiast w złączach wykonanych w powietrzu pęknięcia stwierdzono tylko w jednym z dwóch złączy próbnych.

Twardość maksymalna SWC złączy ze stali S500M nie przekraczała $300 \mathrm{HV}$, natomiast w SWC złączy ze stali S355J2G3 stwierdzono twardość maksymalną powyżej 400 HV10.
Zastosowanie techniki ściegu odpuszczającego spowodowało obniżenie twardości maksymalnej SWC złączy ze stali S355J2G3 do wartości poniżej 350 HV10.

Wykazano skuteczność metody ściegu odpuszczającego dla złączy ze stali o podwyższonej wytrzymałości spawanych pod wodą. Opracowanie technologii TBW dla złączy spawanych metodą mokrą wymaga jednak dalszych badań. 


\section{Literatura}

[1] Ćwiek J.: Niszczenie wodorowe stali spawalnych o wysokiej wytrzymałości. Wydawnictwo Politechniki Gdańskiej, Gdańsk 2006.

[2] Brózda J.: Stale konstrukcyjne i ich spawalność. Instytut Spawalnictwa. Gliwice 2009.

[3] Łabanowski J., Fydrych D., Rogalski G.: Underwater WeIding - a review. Advances in Materials Science 3/2008.

[4] Łomozik M.: Metaloznawstwo i badania metalograficzne połączeń spawanych. Instytut Spawalnictwa. Gliwice 2005.

[5] Tasak E.: Spawalność stali. Wydawnictwo Fotobit. Kraków 2002.

[6] Christensen N.: The metallurgy of underwater welding Proceedings of the International Conference "Underwater Welding", Trondheim, Norway 1983.

[7] Cotton H. C.: Welding under water and in the splash zone - a review. Proceedings of the International Conference „Underwater Welding”, Trondheim, Norway 1983.

[8] Ozaki H., Naiman J., Masubuchi K.: A study of hydrogen cracking in underwater steel welds. Welding Journal 8/1977.

[9] Łabanowski J.: Rozwój technik spawania pod wodą. Przegląd Spawalnictwa 10/2008.

[10] Lesiński K. J.: Stan i perspektywy rozwoju technik spawalniczych pod wodą. Materiały konferencji naukowo-technicznej „Problemy cięcia i spawania pod wodą”, ITMMiS, Gdańsk 1985

[11] Bohme D., Eisenbeis C.: Investigation into the credibility of the implant test when used to asses the cold cracking sensitivity of underwater wet welds. Proceedings of the International Conference „Welding Under Extreme Conditions”, Helsinki, Finland 1989.

[12] Hoffmeister H., Kuster K.: Process variables and properties of underwater wet shielded metal arc laboratory welds. Proceedings of the International Conference „Underwater Welding", Trondheim, Norway 1983.

[13] Skorupa A., Bal M.: Wpływ środowiska wodnego na jakość połączeń spawanych pod wodą. Przegląd Spawalnictwa 3/1986.

[14] Rogalski G., Fydrych D.: Wpływ parametrów spawania pod wodą na twardość złączy. Prace Naukowe Politechniki Warszawskiej. Seria: Mechanika z. 230. Warszawa 2010.

[15] Fydrych D., Rogalski G.: Effect of shielded-electrode wet welding conditions on diffusible hydrogen content in deposited metal. Welding International nr. 3/2011.
[16] Suga Y.: Effect of diffusible hydrogen on mechanical properties of underwater welded joints - study on improving the mechanical properties of underwater welded joints (the 1st report). Transactions of the Japan Welding Society 10/1985.

[17] Brink S. H., Boltje G. W.: Cold cracking susceptibility of weIds obtained by wet underwater welding. Proceedings of the International Conference „Underwater Welding”, Trondheim, Norway 1983.

[18] Walczak W., Fydrych D.: Skłonność złączy wykonanych pod wodą do tworzenia pęknięć zimnych. Prace Naukowe Politechniki Warszawskiej. Seria: Mechanika z. 215. Warszawa 2006.

[19] Tasak E., Bal M.: Struktura i własności spoin wykonanych elektrodami otulonymi pod wodą. Przegląd Spawalnictwa, nr 1-2/1985

[20] Liu S.: Fundamentos de saldatura humeda. Seminario de saldatura humeda. Campeche, Mexico 1999.

[21] Łomozik M.: Morfologia i własności plastyczne obszarów strefy wpływu ciepła w stalowych złączach spawanych w aspekcie użycia ściegów odpuszczających. Uczelniane Wydawnictwa Naukowo-Dydaktyczne AGH, Kraków 2007.

[22] Joint industry underwater welding development program. Phase I - final report. Global Divers \& Contractors, Colorado School of Mines, 1995.

[23] Katalog materiałów spawalniczych firmy Lincoln Electric.

[24] PN-EN ISO 17642-2:2005 Spawalnictwo. Badania niszczące spoin w metalach. Badania pękania na zimno złączy spawanych. Metody spawania łukowego. Część 2: Próby $\mathrm{z}$ utwierdzeniem własnym.

[25] PN-EN 571-1:1999 Badania nieniszczace. Badania penetracyjne. Zasady ogólne.

[26] PN-EN ISO 23277:2010 Badanie nieniszczące spoin. Badanie penetracyjne spoin. Poziomy akceptacji.

[27] PN-EN 1321:2000 Spawalnictwo. Badania niszczące metalowych złączy spawanych. Badania makroskopowe i mikroskopowe złączy spawanych.

[28] PN-EN 1043-1:2000 Spawalnictwo. Badania niszczące metalowych złączy spawanych. Próba twardości. Próba twardości złączy spawanych łukowo.

[29] Rogalski G., Łabanowski J.: Certyfikowanie nurków-spawaczy przy spawaniu mokrym pod wodą w warunkach hiperbarycznych. Biuletyn Instytutu Spawalnictwa, nr 1/2011.

[30] Fydrych D., Łabanowski J.: Oznaczanie ilości wodoru dyfundującego metodą rtęciową. Przegląd Spawalnictwa 06/2009.

\section{W następnym numerze}

W następnym numerze opublikowane zostaną artykuły prezentowane na 53. Krajowej Naukowo-Technicznej Konferencji Spawalniczej Nowe kierunki w procesach spajania i cięcia metali w Poznaniu. 